\title{
Hof van Justitie sluit zich voor het zwijgrecht en het nemo tenetur-beginsel voor natuurlijke personen aan bij het EHRM
}

Mr. M.A.A. Traousis*

In het arrest $D B /$ Consob oordeelt de Grote kamer van het Hof van Justitie over de reikwijdte van het zwijgrecht en het nemo tenetur-beginsel voor natuurlijke personen. Eerder is dit al gedaan voor rechtspersonen in het kader van het mededingingsrecht, maar voor natuurlijke personen breidt het Hof van Justitie dit nu uit door aan te sluiten bij de rechtspraak van het EHRM. Dit leidt ertoe dat iemand geen boete mag krijgen omdat hij weigert te antwoorden, wanneer die antwoorden mogelijk tegen hem zouden kunnen worden gebruikt bij een criminal charge.

Hv7 2 februari 2021, zaak C-481/19, ECLI:EU:C: 2021:84 (DB/Commissione Nazionale per le Società e la Borsa (Consob)).

\section{Inleiding}

Het zwijgrecht en het nemo tenetur-beginsel behoren tot de kernbeginselen van het strafrecht. Zij houden kort gezegd in dat een verdachte het recht heeft om te zwijgen op vragen van de overheid in het kader van een strafrechtelijke vervolging (het zwijgrecht) en dat een verdachte niet aan zijn eigen veroordeling hoeft mee te werken (het nemo tenetur-beginsel). Het Unierecht bevat echter ook verplichtingen mee te werken aan onderzoeken van toezichthoudende autoriteiten naar mogelijke schendingen, zodat deze autoriteiten hun toezichthoudende taken goed kunnen uitoefenen. Het gaat dan bijvoorbeeld om de plicht alle inlichtingen te verstrekken aan de toezichthoudende autoriteit. ${ }^{1}$ Komt de autoriteit vervolgens tot de conclusie dat sprake is van een schending van het Unierecht, dan kan deze autori- teit bevoegd zijn om tegen deze schending op te treden. Als het dan gaat om een sanctie van strafrechtelijke aard is het echter de vraag hoe dit zich verhoudt met het nemo tenetur-beginsel. Daarbij rijst ook de vraag hoe deze medewerkingsplicht zich verhoudt met het zwijgrecht. Kan iemand worden bestraft omdat hij de medewerkingsplicht overtreedt omdat hij zich beroept op zijn zwijgrecht? Deze vragen staan centraal in het arrest $D B / C o n s o b$ van de Grote kamer van het Hof van Justitie. ${ }^{2}$ Daarbij komt met name aan de orde wat voor natuurlijke personen de reikwijdte is van het zwijgrecht en het nemo tenetur-beginsel.

In dit artikel volgt een beschouwing van het arrest $D B$ / Consob. Daarbij zal allereerst worden stilgestaan bij het hoofdgeding en de prejudiciële vragen. Hierna wordt de jurisprudentie over het zwijgrecht en het nemo teneturbeginsel besproken die gold voorafgaand aan dit arrest van zowel het Hof van Justitie als het Europees Hof voor de Rechten van de Mens (EHRM) ter verduidelijking van de conclusie van advocaat-generaal Pikamä $\mathrm{e}^{3}$ en het arrest van het Hof van Justitie, die daarna worden besproken. Hierna wordt bekeken welke veranderingen het arrest $D B /$ Consob met zich brengt voor de eerder besproken jurisprudentie en de uitvoering van het Unierecht, waarna tot slot wordt ingegaan op mogelijke verdere ontwikkelingen van de rechtspraak van het Hof.

\section{Juridisch kader}

Een voorbeeld van de hiervoor besproken medewerkingsverplichting aan onderzoek van een toezichthouder naar een mogelijke schendig van het Unierecht, is te

2. HvJ 2 februari 2021, zaak C-481/19, ECLI:EU:C:2021:84 (DB/Commissione Nazionale per le Società e la Borsa (Consob)).

3. Conclusie A-G Pikamäe 27 oktober 2020, zaak C-481/19, ECLI:EU:C: 2020:861 (DB/Commissione Nazionale per le Società e la Borsa (Consob)), punt 66 . 
vinden in Richtlijn 2003/6/EG. ${ }^{4}$ Deze richtlijn is gericht op het voorkomen van marktmisbruik door bijvoorbeeld het gebruik van voorkennis. Artikel 12 van deze richtlijn kent de toezichthoudende autoriteiten onder meer de bevoegdheden toe om inlichtingen te vorderen van personen en hen op te roepen en te horen, maar ook de toegang tot ieder document en om tijdelijke verboden op beroepsuitoefening op te leggen. Artikel 14 van deze richtlijn bepaalt dat de lidstaten ervoor zorgen dat passende administratieve maatregelen of administratieve sancties kunnen worden opgelegd aan de verantwoordelijke personen indien krachtens deze richtlijn vastgestelde bepalingen niet worden nageleefd. Met name artikel 14 lid 3 Richtlijn 2003/6/EG is voor deze zaak van belang en verplicht lidstaten sancties vast te stellen als niet wordt meegewerkt aan het onderzoek van de toezichthouder. Per 3 juli 2016 is Richtlijn 2003/6/EG ingetrokken en vervangen door de Verordening marktmisbruik. ${ }^{5}$ Ook deze verordening kent in artikel 30 lid 1 onder b een soortgelijke opdracht. ${ }^{6}$

\section{Het hoofdgeding}

In Italië is de Conso $b^{7}$ de bevoegde autoriteit om marktmisbruik tegen te gaan. ${ }^{8}$ De Consob kan bestuurlijke boetes opleggen als wordt gehandeld met voorkennis, maar ook als iemand niet meewerkt aan de verzoeken van de Consob of haar vertraagt in het onderzoek. ${ }^{9}$ De Consob heeft aan DB, een natuurlijke persoon, geldboetes opgelegd voor handel met voorkennis en omdat DB het verhoor meerdere keren heeft verzet en vervolgens weigerde te antwoorden. Ook is de betrouwbaarheidsstatus van DB tijdelijk ingetrokken en is de winst van de voorkennis ontnomen. DB is tegen deze sancties opgekomen en is uiteindelijk uitkomen bij de Corte constituzionale. De Corte constituzionale heeft vervolgens prejudiciële vragen voorgelegd aan het Hof van Justitie. Deze vragen houden in of artikel 14 lid 3 Richtlijn 2003/6/EG en artikel 30 lid 1 onder b Verordening

4. Richtlijn 2003/6/EG van het Europees Parlement en de Raad van 28 januari 2003 betreffende handel met voorwetenschap en marktmanipulatie (marktmisbruik) (PbEU 2003, L 96/16-25).

5. Verordening (EU) nr. 596/2014 van het Europees Parlement en de Raad van 16 april 2014 betreffende marktmisbruik (verordening marktmisbruik) en houdende intrekking van richtlijn 2003/6/EG van het Europees Parlement en de Raad en richtlijnen 2003/124/EG, 2003/125/EG en 2004/72/EG van de Commissie (PbEU 2014, L 173/1-61).

6. De Verordening marktmisbruik heeft echter als doel een uniformer en sterker kader te creëren. Zo krijgt de toezichthouder sterkere bevoegdheden voor toezicht, onderzoek en sancties. Voor deze sancties kent art. 30 een uitbreiding van de voorschriften waaraan de nationale regelingen van lidstaten moeten voldoen. Zie overweging 4 van de preambule bij de Verordening marktmisbruik.

7. Voluit: Commissione Nazionale per le Società e la Borsa.

8. In Nederland is de Stichting Autoriteit Financiële Markten (AFM) de bevoegde autoriteit.

9. Art. 187 quinquiesdecies van de geconsolideerde tekst van de bepalingen inzake financiële bemiddeling in de zin van de artikelen 8 en 21 van wet nr. 52 (Testo unico delle disposizioni in materia di intermediazione finanziaria, ai sensi degli articoli 8 e 21 della legge 6 febbraio 1996, n. 52). marktmisbruik zo moeten worden uitgelegd dat een lidstaat mag besluiten geen sanctie op te leggen aan iemand die weigert vragen van de bevoegde autoriteit te beantwoorden waaruit zou kunnen blijken dat hij zich schuldig heeft gemaakt aan een strafbaar feit dat met bestraffende administratieve sancties wordt bestraft. Indien deze bepalingen niet zo moeten worden uitgelegd, vraagt de Corte constituzionale of de genoemde artikelen van Richtlijn 2003/6/EG en de Verordening marktmisbruik verenigbaar zijn met artikel 47 en 48 Handvest van de grondrechten van de Europese Unie (Handvest), de rechtspraak van het EHRM en de grondwettelijke tradities van de lidstaten, voor zover in de hiervoor genoemde situatie een sanctie moet worden opgelegd. Over de boete voor het weigeren te antwoorden overweegt de verwijzende rechter dat een verdachte door de medewerkingsplicht in feite meewerkt aan zijn eigen vervolging. De Corte constituzionale wijst op de rechtspraak van het EHRM waaruit volgt dat het zwijgrecht en het nemo tenetur-beginsel in dergelijke gevallen worden geschonden. ${ }^{10}$

\section{De geldende Europese jurisprudentie over zwijgrecht en nemo tenetur-beginsel voorafgaande aan $D B /$ Consob}

Zoals ook al uit de prejudiciële vragen van de Corte constituzionale blijkt, heeft het EHRM al rechtspraak over het zwijgrecht en het nemo tenetur-beginsel. Ook het Hof van Justitie heeft hier al diverse uitspraken over gedaan. Om een goede weergave te kunnen geven van de conclusie van advocaat-generaal Pikamäe en het arrest van het Hof van Justitie, wordt hier eerst een overzicht gegeven van beide jurisprudentielijnen voorafgaand aan $D B /$ Consob.

Het Hof van Justitie: het zwijgrecht en het nemo tenetur-beginsel voor rechtspersonen

Het Hof van Justitie heeft zich vóór het arrest $D B$ / Consob alleen nog maar uitgelaten over de reikwijdte van het zwijgrecht en het nemo tenetur-beginsel voor rechtspersonen. In het standaardarrest Orkem/ Commissie heeft het Hof van Justitie geoordeeld dat ondernemingen waartegen een onderzoek loopt naar een mogelijke inbreuk van de mededingingsregels, verplicht zijn om actief mee te werken aan dit onderzoek. ${ }^{11} \mathrm{Zij}$ moeten daarom alle informatie (zoals inlichtingen en documenten) aan de Europese Commissie geven als die nodig zijn. Deze verplichting geldt ook als de inlichtin-

10. EHRM 3 mei 2001, ECLI:CE:ECHR:2001:0503JUD003182796 (J.B./ Zwitserland), punt 63-71; EHRM 4 oktober 2005, ECLI:CE:ECHR: 2005:1004JUD000656303 (Shannon/Verenigd Koninkrijk), punt 38-41; en EHRM 5 april 2012, ECLI:CE:ECHR:2012:0405JUD001166304 (Chambaz/Zwitserland), punt 50-58.

11. HvJ 18 oktober 1989, zaak C-374/87, ECLI:EU:C:1989:387 (Orkem/ Commissie (verdedigingsrecht mededingingsrecht)). 
gen of documenten bewijs kunnen opleveren van een gedraging van die onderneming zelf die in strijd is met de mededingingsregels. Het verdedigingsrecht van de onderneming mag daarbij echter niet worden geschonden. ${ }^{12}$ Zo kan een onderneming niet worden verplicht om inlichtingen te geven waardoor de inbreuk op de mededingingsregels wordt erkend. Het verdedigingsrecht van de onderneming gaat dan voor en de onderneming hoeft die inlichtingen niet te verstrekken. ${ }^{13}$

Het Hof van Justitie komt in het arrest Orkem/ Commissie op de volgende wijze tot de bovenstaande jurisprudentie. Het stelt voorop dat uit de toepasselijke Verordening $17^{14}$ volgt dat ondernemingen waartegen een mededingingsrechtelijk onderzoek loopt slechts bepaalde specifieke waarborgen hebben. Het recht om geen inlichtingen te hoeven verstrekken als die inlichtingen het bewijs kunnen opleveren dat de mededingingsregels zijn overtreden, behoort niet tot een van die waarborgen. Integendeel, Verordening 17 legt de onderneming een actieve medewerkingsverplichting aan het onderzoek op. Orkem stelde dat met die medewerkingsverplichting het zwijgrecht en het nemo teneturbeginsel worden geschonden. In Verordening 17 is het zwijgrecht niet uitdrukkelijk erkend, waarna het Hof van Justitie onderzoekt of uit de algemene beginselen van het gemeenschapsrecht een recht volgt om geen inlichtingen te hoeven verstrekken als die als bewijs kunnen dienen voor een overtreding van de mededingingsregels. In de rechtsstelsels van de lidstaten komt dat recht alleen toe aan natuurlijke personen die strafrechtelijk worden vervolgd. Uit de nationale rechtsstelsels kan dus niet worden geconcludeerd dat het nemo tenetur-beginsel geldt voor rechtspersonen en met betrekking tot inbreuken van economische aard, in bijzonder in het mededingingsrecht. Het Hof van Justitie overweegt dat ook uit artikel 6 Europees Verdrag tot bescherming van de rechten van de mens en de fundamentele vrijheden (EVRM) en de rechtspraak van het EHRM, dit recht niet kan worden afgeleid. ${ }^{15}$ Tot slot kijkt het Hof van Justitie naar artikel 14 Internationaal Verdrag inzake burgerrechten en politieke Rechten (IVBPR). Die bepaling erkent het zwijgrecht en het nemo tenetur-beginsel wel uitdrukkelijk, maar de reikwijdte daarvan is ook beperkt tot een strafrechtelijke vervolging. ${ }^{16}$ Het Hof van Justitie wijkt daarom uit naar het vereiste van eerbiediging van het verdedigingsrecht, een van de grondbeginselen van de communautaire rechtsorde. ${ }^{17}$ Het Hof van Justitie heeft eerder al geoor-

12. Orkem/Commissie, punt 34

13. Orkem/Commissie, punt 35.

14. Verordening nr. 17: Eerste verordening over de toepassing van de artikelen 85 en 86 van het Verdrag van de Raad van de Europese Economische Gemeenschap van 6 februari 1962 (PbEG 1962, nr. 13/204-211).

15. Inmiddels heeft het EHRM uitgebreide jurisprudentie over het zwijgrecht en het nemo tenetur-beginsel, maar dit heeft het gebaseerd op de algemeen erkende rechtsnormen en volgt dus niet uitdrukkelijk uit art. 6 EVRM, zoals hierna zal worden besproken.

16. Art. 14 lid 3 onder $g$ IVBPR.

17. Zie ook HvJ 9 november 1983, zaak 322/81, ECLI:EU:C:1983:313 (NV Nederlandsche Banden Industrie Michelin/Commissie EG (misbruik van machtspositie, verdedigingsrecht)). deeld dat het recht van verdediging ook moet worden geëerbiedigd in administratieve procedures die kunnen leiden tot de oplegging van sancties en dat moet worden voorkomen dat dit verdedigingsrecht onherstelbare schade lijdt in het vooronderzoek dat beslissend kan zijn voor de totstandkoming van bewijs van onrechtmatige gedragingen van ondernemingen. ${ }^{18}$ Het Hof van Justitie komt op die grond tot het oordeel dat een inlichtingenverplichting mag, tenzij daarmee het verdedigingsrecht wordt geschonden. Zo kan een onderneming door de Commissie niet worden verplicht antwoorden te geven als daarmee het bestaan van de inbreuk van de mededingingsregels moet worden erkend. ${ }^{19}$

Uit Orkem/Commissie volgt dat het zwijgrecht voor rechtspersonen niet absoluut is. Ondernemingen zijn verplicht antwoord geven op vragen, tenzij zij daarmee in wezen toegeven dat zij de mededingingsregels hebben overtreden. ${ }^{20}$ In latere rechtspraak van het Hof van Justitie is overwogen dat een absoluut zwijgrecht immers verder gaat dan noodzakelijk om het verdedigingsrecht van ondernemingen te beschermen en dat de Commissie daarmee ongerechtvaardigd zou worden belemmerd in haar taakuitoefening. ${ }^{21}$ Als het gaat om zuiver feitelijke vragen, zoals dat in de latere jurisprudentie wordt genoemd, kan een onderneming zich dus niet succesvol beroepen op haar verdedigingsrecht om geen inlichtingen te hoeven geven. ${ }^{22}$ De onderneming kan later bij de rechter wel aantonen dat de verstrekte feitelijke inlichtingen en documenten een andere betekenis hebben dan de Commissie daaraan geeft, waardoor het verdedigingsrecht kan worden uitgeoefend. ${ }^{23}$ Het zwijgrecht en het nemo tenetur-beginsel staan er volgens de rechtspraak van het Hof van Justitie niet aan in de weg dat een onderneming verplicht is inlichtingen te verstrekken over feiten waarvan zij kennis heeft, zelfs als daarmee door de Commissie het bewijs kan worden geleverd dat deze onderneming in strijd handelt met het mededingingsrecht. Deze jurisprudentielijn is later meermaals bevestigd en aangevuld. ${ }^{24}$ Daarbij is ook

18. HvJ 21 september 1989, gevoegde zaken C-46/87 en C-227/88, ECLI:EU:C:1989:337 (Hoechst AG/Commissie (grondrecht van onschendbaarheid van de woning)), punt 15.

19. Orkem/Commissie, punt 26-35.

20. HvJ 15 oktober 2002, gevoegde zaken C-238/99 P, C-244/99 P C-245/99 P, C-247/99 P, C-250/99 P, C-252/99 P en C-254/99 P, ECLI:EU:C:2002:582 (Limburgse Vinyl Maatschappij e.a./Commissie), punt 273. Zie in dit verband de conclusie van A-G Wahl van 15 oktober 2015, zaak C-247/14 P, ECLI:EU:C:2015:694 (HeidelbergCement AG/(Commissie), punt 154.

21. Zie bijvoorbeeld Gerecht EU 28 april 2010, zaak T-446/05, ECLI:EU:T: 2010:165 (Amann \& Söhne en Cousin Filterie/Commissie), punt 327.

22. Zie GvEA EG 20 februari 2001, zaak T-112/98, ECLI:EU:T:2001:61 (Mannesmannröhren-Werke/Commissie), punt 66 en 78; HvJ 29 juni 2006, zaak C-301/04, ECLI:EU:C:2006:432 (Commissie/SGL Carbon), punt 49; Amann \& Söhne en Cousin Filterie/Commissie, punt 326 en 328; en Gerecht EU 14 maart 2014, zaak T-297/11, ECLI:EU:T: 2014:122 (Buzzi Unicem/Commissie), punt 60 en 62.

23. Mannesmannröhren-Werke/Commissie, punt 78.

24. Zie o.a. Mannesmannröhren-Werke/Commissie, punt 65; Limburgse Vinyl Maatschappij e.a./Commissie, punt 273; Commissie/SGL Carbon, punt 41; HvJ 24 september 2009, gevoegde zaken C-125/07 P, C-133/07 P en C-137/07 P, ECLI:EU:C:2009:576 (Erste Group Bank e.a./Commissie), punt 271; en HvJ 25 januari 2007, zaak C-407/04 P, ECLI:EU:C:2007:53 (Dalmine/Commissie), punt 34. 
geoordeeld dat de beperkte reikwijdte van het zwijgrecht en het nemo tenetur-beginsel voor rechtspersonen in overeenstemming is met artikel 47 en 48 Handvest, maar ook met artikel 6 EVRM. ${ }^{25}$

Het EHRM: het zwijgrecht en het nemo teneturbeginsel voor natuurlijke personen

Op het moment dat het Hof van Justitie het Orkem/ Commissie-arrest wees, in 1989, waren het zwijgrecht en het nemo tenetur-beginsel nog onbekende termen in de rechtspraak van het EHRM. In de loop der jaren na Orkem/Commissie heeft het EHRM zich echter ook veelvuldig uitgelaten over het zwijgrecht en het nemo tenetur-beginsel, die onder het recht op een eerlijk proces uit artikel 6 EVRM vallen. Daarbij is het belangrijk dat de waarborgen uit artikel 6 EVRM alleen kunnen worden ingeroepen door iemand die met een criminal charge wordt vervolgd. Voor het antwoord op de vraag wanneer sprake is van een criminal charge, moet worden gekeken naar de drie criteria die volgen uit het standaardarrest Engel e.a./Nederland. ${ }^{26}$ Het gaat, samengevat, om de kwalificatie van de overtreding in het nationale recht, de aard van de overtreding, en de zwaarte van de sanctie die kan worden opgelegd aan de overtreder. Het Hof van Justitie heeft deze criteria ook gehanteerd in het Bonda-arrest. ${ }^{27}$ Wordt voldaan aan de Engel-criteria, dan kan een beroep worden gedaan op artikel 6 EVRM. Een criminal charge is dus niet beperkt tot het strafrecht, maar kan ook voorkomen in het bestuursrecht als een sanctie voldoet aan de drie Engelcriteria.

Het EHRM spreekt zich in 1993, enkele jaren na Orkem/Commissie, in het arrest Funke/Frankrijk voor het eerst uit over het zwijgrecht en het nemo teneturbeginsel. ${ }^{28}$ Het EHRM oordeelt dat het nemo teneturbeginsel in deze zaak is geschonden, omdat de Franse douane heeft geprobeerd om Funke zelf bewijs te laten leveren voor overtredingen door boetes op te leggen, zonder dat de douane wist of het bewijs bestond. Dat deze boetes wettelijk opgelegd mochten worden, is geen rechtvaardiging voor de inbreuk op het zwijgrecht en het nemo tenetur-beginsel, zo oordeelt het EHRM. ${ }^{29}$ In Fohn Murray/Verenigd Koninkrijk gaat het EHRM vervolgens uitvoeriger in op beide grondrechten. ${ }^{30}$ Het EHRM overweegt in dit arrest ditmaal uitdrukkelijk dat, hoewel artikel 6 EVRM niet spreekt over het zwijgrecht of het nemo tenetur-beginsel, beide grondrechten algemeen erkende internationale standaarden zijn die tot de kern behoren van het recht op een eerlijk proces. Door de verdachte te beschermen tegen onrechtmatige dwang door de overheid, wordt gerechtelijke dwaling

25. Buzzi Unicem/Commissie, punt 61 en 62 en Amann \& Söhne en Cousin Filterie/Commissie, punt 327

26. EHRM 8 juni 1976, ECLI:CE:ECHR:1976:0608JUD000510071 (Engel e.a./Nederland).

27. HvJ 5 juni 2012, zaak C-489/10, ECLI:EU:C:2012:319 (Bonda/Polen).

28. EHRM 25 februari 1993, ECLI:CE:ECHR:1993:0225JUD001082884 (Funke/Frankrijk)

29. Funke/Frankrijk, punt 41 en 44.

30. EHRM 8 februari 1996, ECLI:CE:ECHR:1996:0208JUD001873191 (John Murray/Verenigd Koninkrijk). voorkomen en draagt dit bij aan de doelstellingen van artikel 6 EVRM. $^{31}$ In Saunders/Verenigd Koninkrijk voegt het EHRM hieraan toe dat het nemo teneturbeginsel primair ziet op het respecteren van de wil van de verwachte om te zwijgen. ${ }^{32}$ Dit beginsel gaat echter niet zo ver dat materiaal dat onder dwang is verkregen maar ook bestaat buiten de wil van de verdachte (wilsonafhankelijk materiaal), niet mag worden gebruikt in een strafrechtelijke procedure. Wilsonafhankelijke materialen kunnen bijvoorbeeld documenten zijn, maar ook lichamelijk materiaal als bloed. ${ }^{33}$ Verder is van belang dat bij onrechtmatige dwang van de overheid niet alleen moet worden gedacht aan het verkrijgen van materiaal door middel van geweld (denk aan foltering), ${ }^{34}$ maar ook aan het dreigen met sancties om tot een bekentenis te komen, ${ }^{35}$ het misleiden van de verdachte om hem te laten bekennen ${ }^{36}$ of tot het straffen omdat iemand weigert te antwoorden. ${ }^{37}$

Omdat $D B /$ Consob draait om het dreigen met sancties om een overtreding te bekennen en het opleggen van een boete omdat DB weigerde vragen te beantwoorden, zal dieper worden ingegaan op deze twee vormen van dwang. Het EHRM onderzoekt eerst of sprake is van dwang en vervolgens of deze dwang onrechtmatig is. Wanneer iemand weigert te antwoorden moet om vast te stellen of sprake is van dwang eerst worden gekeken naar de aard en mate van de sanctie die wordt opgelegd als iemand geen antwoord geeft en of de procedure daar passende garanties tegen biedt. ${ }^{38}$ Hoewel het EHRM oordeelt dat het zwijgrecht niet absoluut is, betekent dat niet dat de overheid zodanige dwang mag uitoefenen dat de kern van dit recht wordt uitgehold. ${ }^{39}$ Daarvoor is met name van belang hoe dit materiaal dat met dwang is verkregen wordt gebruikt in de strafprocedure, zowel binnen de context van de procedure als daarbuiten. ${ }^{40}$ Verder is van belang dat het zwijgrecht niet alleen ziet op bekentenissen en andere opmerkingen waarmee iemand rechtstreeks in verband kan worden gebracht met een overtreding. Ook antwoorden op feitelijke vra-

31. John Murray/Verenigd Koninkrijk, punt 45.

32. EHRM 17 december 1996, ECLI:CE:ECHR:1996:1217JUD001918791 (Saunders/Verenigd Koninkrijk).

33. Saunders/Verenigd Koninkrijk, punt 69.

34. Zie bijvoorbeeld EHRM 11 juli 2006, ECLI:CE:ECHR:2006:0711 JUD005481000 (Jalloh/Duitsland); EHRM 6 september 2000, ECLI:CE:ECHR:2000:0606JUD002813595 (Magee/Verenigd Koninkrijk); en EHRM 1 juni 2010, ECLI:CE:ECHR:2010:0601 JUD002297805 (Gäfgen/Duits/and)

35. Zie bijvoorbeeld Saunders/Verenigd Koninkrijk; EHRM 14 oktober 2010, ECLI:CE:ECHR:2010:1014JUD000146607 (Brusco/Frankrijk); en Funke/Frankrijk.

36. Zie bijvoorbeeld EHRM 12 juli 2013, ECLI:CE:ECHR:2013:0712 JUD002542409 (Allen/Verenigd Koninkrijk).

37. EHRM 21 december 2000, ECLI:CE:ECHR:2000:1221JUD003472097 (Heaney en McGuinness/lerland); EHRM 8 april 2004, ECLI:CE:ECHR: 2004:0408JUD003854497 (Weh/Oostenrijk).

38. Heaney en McGuinness/lerland, punt 53 en EHRM 29 juni 2007, ECLI:CE:ECHR:2007:0629JUD001580902 (O'Halloran en Francis/ Verenigd Koninkrijk), punt 59.

39. John Murray/Verenigd Koninkrijk, punt 47.

40. Saunders/Verenigd Koninkrijk, punt 71; Weh/Oostenrijk, punt 42-44; en EHRM 13 september 2016, ECLI:CE:ECHR:2016:0913 JUD005054108 (Ibrahim e.a./Verenigd Koninkrijk), punt 269. 
gen vallen hieronder als zij later kunnen worden gebruikt om tot een veroordeling te komen of om een sanctie op te leggen. ${ }^{41}$ Dat met het vervolgen een algemeen belang wordt nagestreefd, levert geen rechtvaardiging op om de reikwijdte van het zwijgrecht en het nemo tenetur-beginsel te beperken. ${ }^{42}$ Tot slot moet worden vastgesteld dat het EHRM ook diverse malen het zwijgrecht en het nemo tenetur-beginsel heeft toegekend in het kader van (bestraffend) bestuursrechtelijke overtredingen. ${ }^{43}$

Het EHRM oordeelt dus dat indien sprake is van een criminal charge, het recht op een eerlijk proces ook het zwijgrecht en het nemo tenetur-beginsel omvat. Anders dan het Hof van Justitie daarvoor in onder andere het arrest Orkem/Commissie oordeelde, gelden deze twee grondrechten ook als feitelijke vragen worden gesteld. Daarvoor geldt wel dat die feitelijke vragen later mogelijk gebruikt kunnen worden om tot een veroordeling te komen of een sanctie op te leggen. Een belangrijker verschil is echter dat het EHRM het zwijgrecht en het nemo tenetur-beginsel nog alleen heeft erkend voor natuurlijke personen, terwijl het Hof van Justitie zich nog slechts heeft uitgesproken over deze rechten voor rechtspersonen.

\section{Conclusie van advocaat-generaal Pikamäe}

$\mathrm{Na}$ deze (uitgebreide) uitstap naar de rechtspraak van het Hof van Justitie en het EHRM over het zwijgrecht en het nemo tenetur-beginsel, kan de conclusie van advocaat-generaal Pikamäe worden besproken. ${ }^{44}$ Net als het Hof van Justitie en het EHRM eerder hebben gedaan, ${ }^{45}$ onderzoekt Pikamäe eerst of het zwijgrecht en het nemo tenetur-beginsel uitdrukkelijk zijn vastgelegd. Omdat artikel 47 en 48 Handvest deze rechten niet expliciet bevatten, kijkt hij op basis van artikel 52 lid 3 Handvest - dat bepaalt dat de inhoud en reikwijdte van de door het Handvest erkende rechten gelijk zijn aan de inhoud en reikwijdte van corresponderende EVRMrechten - naar artikel 6 EVRM. ${ }^{46}$ Deze twee grondrechten zijn door het EHRM wel erkend, waarna Pikamäe een overzicht geeft van de hiervoor besproken EHRM-

41. Zie Saunders/Verenigd Koninkrijk, punt 71 en EHRM 19 maart 2015, ECLI:CE:ECHR:2015:0319JUD000749411 (Corbet e.a./Frankrijk), punt 34.

42. Saunders/Verenigd Koninkrijk, punt 74

43. J.B./Zwitserland, Shannon/Verenigd Koninkrijk en Chambaz/Zwitserland.

44. Conclusie A-G Pikamäe 27 oktober 2020, zaak C-481/19, ECLI:EU:C: 2020:861 (DB/Commissione Nazionale per le Società e la Borsa (Consob))

45. Zie respectievelijk Orkem/Commissie, punt 28-31 en John Murray/ Verenigd Koninkrijk, punt 45.

46. Uit de Toelichtingen bij het Handvest volgt dat de waarborgen uit art. 6 lid 1 EVRM op dezelfde wijze van toepassing zijn bij art. 47 lid 2 Handvest en dat art. 48 lid 1 Handvest dezelfde inhoud en reikwijdte heeft als artikel 6 lid 2 EVRM. Zie Toelichtingen bij het Handvest van de grondrechten (PbEU 2007, C 303/17). jurisprudentie. Pikamäe stelt vervolgens vast dat volgens de rechtspraak van het EHRM het zwijgrecht en het nemo tenetur-beginsel automatisch gelden als sprake is van een 'criminal charge' volgens het Bonda-arrest, ook bij bestuursrechtelijke procedures. ${ }^{47}$

Pikamäe analyseert vervolgens of artikel 14 lid 3 Richtlijn 2003/6/EG en artikel 30 lid 1 onder b Verordening marktmisbruik in overeenstemming met deze twee grondrechten kunnen worden uitgelegd. Is dat het geval, dan betekent dit dat de artikelen een lidstaat niet dwingen om een sanctie op te leggen aan iemand die weigert antwoord te geven op de vragen van toezichthoudende autoriteiten waaruit zou kunnen blijken dat hij zich schuldig heeft gemaakt aan een overtreding die met een punitieve administratieve sanctie wordt bestraft. ${ }^{48} \mathrm{Op}$ basis van een systematische en historische uitleg van deze bepalingen komt Pikamäe tot de conclusie dat zij in overeenstemming met het zwijgrecht kunnen worden uitgelegd. $\mathrm{Zij}$ verplichten namelijk niet dat de opgelegde sanctie ook van strafrechtelijke aard moet zijn. ${ }^{49}$ De wetgever heeft volgens Pikamäe ook niet beoogd dat verplicht met sancties van strafrechtelijke aard moet worden opgetreden. De richtlijn en verordening vormen namelijk slechts een minimumharmonisatie. ${ }^{50}$ De Uniewetgever heeft een ruime beoordelingsbevoegdheid toegekend aan de lidstaten en heeft deze lidstaten vrijgelaten bij het bepalen van de aard en omvang van de sancties in het geval de medewerkingsverplichting wordt geschonden. Pikamäe concludeert dat de Uniewetgever met deze beoordelingsbevoegdheid en de erkenning van de grondrechten uit het Handvest ${ }^{51}$ heeft erkend dat het opleggen van een sanctie kan worden uitgesloten als de Handvest-grondrechten daarmee in het geding komen. Voor deze zaak betekent het dus dat een sanctie voor het schenden van de medewerkingsverplichting in overeenstemming moet zijn met het zwijgrecht en het nemo tenetur-beginsel uit artikel 47 en 48 Handvest. ${ }^{52}$

Omdat artikel 14 lid 3 Richtlijn 2003/6/EG en artikel 30 lid 1 onder b Verordening marktmisbruik volgens Pikamäe conform het Handvest kunnen worden uitgelegd, gaat hij vervolgens in op de reikwijdte van het zwijgrecht en het nemo tenetur-beginsel. Anders dan de Italiaanse regering meent, moet de Orkem/Commissiejurisprudentie niet naar analogie worden toegepast wanneer de reikwijdte van het zwijgrecht van natuurlijke personen moet worden vastgesteld, aldus Pikamäe. ${ }^{53}$ Die reikwijdte geldt immers alleen voor rechtspersonen. Pikamäe zet uiteen dat uit de EHRM-rechtspraak volgt dat het zwijgrecht en het nemo tenetur-beginsel ook gelden voor natuurlijke personen in administratieve procedures die kunnen leiden tot een punitieve sanctie.

\footnotetext{
47. Conclusie A-G, DB/Consob, punt 49-61.

48. Conclusie A-G, DB/Consob, punt 62 .

49. Conclusie $\mathrm{A}-\mathrm{G}, \mathrm{DB} /$ Consob, punt 73-76.

50. Conclusie A-G, DB/Consob, punt 77.

51. Overweging 44 van de preambule van Richtlijn 2003/6 en overweging 77 van de preambule van de Verordening marktmisbruik.

52. Conclusie $\mathrm{A}-\mathrm{G}, \mathrm{DB} /$ Consob, punt 78-79.

53. Conclusie $\mathrm{A}-\mathrm{G}, \mathrm{DB} /$ Consob, punt 94-95.
} 
Antwoorden op feitelijke vragen, ook als zij geen schuldbekentenis inhouden, vallen onder deze reikwijdte, mits deze van invloed zijn op de motivering van de beslissing of op de an het einde van die procedure opgelegde sanctie. Bij de vaststelling van de reikwijdte van dat recht is het algemene belang bij de vervolging van de betrokken inbreuk niet relevant. ${ }^{54}$ Ook in het arrest Fussila/Finland dat de Italiaanse regering aanhaalt, vindt Pikamäe geen steun om de reikwijdte van beide rechten te beperken tot de afgezwakte versie die geldt voor rechtspersonen. Uit het fussila-arrest volgt dat niet alle strafrechtelijke waarborgen in procedures die niet tot 'de harde kern van het strafrecht' behoren geheel naar de letter hoeven te worden toegepast. ${ }^{55}$ Anders dan in het Fussila-arrest, dat draaide om een belastingprocedure, gaat het bij $D B / C o n s o b$ namelijk wel om een procedure die tot 'de harde kern van het strafrecht' hoort in de zin van de EHRM-rechtspraak. ${ }^{56}$ Daar komt bij dat het zwijgrecht en het nemo teneturbeginsel tot de kern van het recht op een eerlijk proces behoren, waardoor Pikamäe van mening is dat deze waarborgen wel strikt moeten worden toegepast. Verder volgt uit Fussila ook niet dat een strafrechtelijke waarborg afgeschaft of beperkt kan worden, maar enkel dat deze waarborgen met een alternatief worden vervangen om het recht op een eerlijk proces te beschermen. ${ }^{57}$

Pikamäe concludeert daarom, gelet op het voorgaande, dat de reikwijdte van het zwijgrecht en het nemo tenetur-beginsel voor natuurlijke personen in het kader van een administratieve procedure die kan leiden tot het opleggen van een sanctie van strafrechtelijke aard, moet overeenkomen met de reikwijdte die volgt uit de rechtspraak van het EHRM, onder verwijzing naar artikel 52 lid 3 Handvest. Daarbij benadrukt hij dat beide grondrechten ook moeten gelden voor antwoorden op feitelijke vragen die van invloed zijn op de motivering van de beslissing of op de aan het einde van de procedure opgelegde sanctie. ${ }^{58}$

\section{Arrest van de Grote Kamer}

Ook het Hof van Justitie verwijst naar artikel 52 lid 3 Handvest en overweegt dat bij de uitleg van artikel 47 en 48 Handvest rekening moet worden gehouden met de corresponderende rechten uit artikel 6 EVRM. ${ }^{59}$ Het betrekt in zijn overwegingen, net als Pikamäe, de jurisprudentie van het EHRM met betrekking tot het zwijgrecht en het nemo tenetur-beginsel. Het Hof van Justitie oordeelt vervolgens dat deze twee beginselen geen rechtvaardiging bieden voor elke weigering van samenwerking met een toezichthoudende autoriteit, zoals het

54. Conclusie A-G, DB/Consob, punt 106.

55. EHRM 23 november 2006, ECLI:CE:ECHR:2006:1123JUD007305301 (Jussila/Finland), punt 43.

56. EHRM 4 maart 2014, ECLI:CE:ECHR:2014:0304JUD001864010 (Grande Stevens e.a./Italië), punt 122.

57. Conclusie A-G, DB/Consob, punt 113.

58. Conclusie A-G, $D B /$ Consob, punt 117.

59. $D B /$ Consob, punt 36-37. weigeren om te verschijnen op een hoorzitting of het toepassen van vertragingstactieken. ${ }^{60}$ Het Hof van Justitie overweegt dat dezelfde sancties die aan DB zijn opgelegd al in eerdere arresten van zowel het Hof van Justitie als het EHRM zijn aangemerkt als een 'criminal charge' ${ }^{61}$ Wanneer de door de toezichthouder opgelegde sancties echter geen criminal charge zouden zijn, dan nog zouden het zwijgrecht en het nemo tenetur-beginsel gewaarborgd moeten worden in het administratieve onderzoek omdat hieruit bewijs kan worden verkregen dat tegen dezelfde persoon in een strafrechtelijke procedure kan worden gebruikt. ${ }^{62}$ Gelet op artikel 52 lid 3 Handvest en de EHRM-jurisprudentie oordeelt het Hof van Justitie dat het zwijgrecht en het nemo teneturbeginsel van natuurlijke personen tegen wie een criminal charge loopt, worden gewaarborgd door artikel 47 en 48 Handvest. Die waarborgen moeten door alle instellingen van de Unie en, wanneer zij het Unierecht ten uitvoer brengen, de lidstaten in acht worden genomen, op basis van artikel 51 lid 1 Handvest. ${ }^{63}$ Deze twee grondrechten verzetten zich er onder andere tegen dat deze personen een sanctie wordt opgelegd omdat zij weigeren antwoord te geven aan de toezichthoudende autoriteiten, als uit deze antwoorden zou kunnen blijken dat zij zich schuldig hebben gemaakt aan een inbreuk waarvoor zij worden bestraft met strafrechtelijke sancties of administratieve sancties van strafrechtelijke aard. ${ }^{64}$ Het Hof van Justitie overweegt vervolgens uitdrukkelijk dat de jurisprudentie over de reikwijdte van het zwijgrecht en het nemo tenetur-beginsel dat aan rechtspersonen is toegekend, niet analoog kan worden toegepast op natuurlijke personen zoals DB. ${ }^{65}$ Die jurisprudentie ziet namelijk alleen op rechtspersonen en daar komt bij dat ook ondernemingen geen antwoord hoeven te geven op vragen als zij daarmee een overtreding bekennen.

Nadat het Hof van Justitie heeft geoordeeld wat de reikwijdte van deze twee Handvest-grondrechten is voor natuurlijke personen, ligt de vraag voor of artikel 14 lid 3 Richtlijn 2003/6/EG en artikel 30 lid 1 onder b Verordening marktmisbruik in overeenstemming met het Handvest kunnen worden uitgelegd. Het Hof van Justitie brengt daarbij in herinnering dat een bepaling van afgeleid Unierecht volgens het algemeen uitleggingsbeginsel zo mogelijk moet worden uitgelegd dat geen afbreuk wordt gedaan aan de geldigheid van die bepaling, en het primaire Unierecht, waaronder met name de bepalingen van het Handvest, in acht wordt genomen. Kan een bepaling op meerdere manieren worden uitgelegd, dan krijgt de uitleg die niet in strijd is

60. $D B /$ Consob, punt 38-41

61. HvJ 20 maart 2018, gevoegde zaken C-596/16 en C-597/16, ECLI:EU:C:2018:192 (Di Puma en Zecca/Commissie); Grande Stevens e.a./Italië.

62. $D B /$ Consob, punt $43-44$.

63. $D B /$ Consob, punt 35

64. $D B /$ Consob, punt 45 .

65. $D B /$ Consob, punt $46-48$. 
met het recht de voorkeur. ${ }^{66}$ Het Hof van Justitie overweegt dat in zowel de preambule van Richtlijn 2003/6/EG als de Verordening marktmisbruik staat dat de grondrechten worden geëerbiedigd en het Handvest in acht wordt genomen ${ }^{67}$ Omdat zowel artikel 14 lid 3 Richtlijn 2003/6/EG als artikel 30 lid 1 onder b Verordening marktmisbruik niet verplicht dat een sanctie wordt opgelegd aan een natuurlijke persoon omdat deze weigert antwoorden te geven aan toezichthoudende autoriteiten waaruit zou kunnen blijken dat zij schuldig zijn aan een overtreding die strafrechtelijk of met bestraffend bestuursrecht wordt bestraft, oordeelt het Hof van Justitie dat beide artikelen conform artikel 47 en 48 Handvest kunnen worden uitgelegd. ${ }^{68}$ Het Hof van Justitie brengt daarbij in herinnering dat lidstaten hun beoordelingsbevoegdheid die zij van afgeleid Unierecht krijgen, zo moeten gebruiken dat dit in overeenstemming is met de grondrechten. ${ }^{69}$ Dit betekent dat de lidstaten ervoor moeten zorgen dat de toezichthouders een natuurlijke persoon geen sanctie kunnen opleggen omdat deze weigert antwoorden te geven waaruit zou kunnen blijken dat hij zich schuldig heeft gemaakt aan een overtreding die met het strafrecht of bestraffend bestuursrecht wordt bestraft. ${ }^{70}$

\section{Commentaar}

Uit het arrest $D B /$ Consob volgt voor het eerst dat het zwijgrecht en het nemo tenetur-beginsel ook gelden voor natuurlijke personen in het kader van het Unierecht. Het Hof van Justitie volgt hier inhoudelijk de conclusie van Pikamäe en oordeelt dat natuurlijke personen geen sanctie opgelegd mogen krijgen als zij weigeren antwoorden te geven, voor zover uit die antwoorden zou kunnen blijken dat zij een overtreding hebben begaan die strafrechtelijk of met bestraffend bestuursrecht wordt bestraft. Daarbij wordt met de reikwijdte van artikel 47 en 48 Handvest aangesloten bij de rechtspraak van het EHRM en sluit het Hof van Justitie voor wat betreft natuurlijke personen expliciet niet aan bij de reikwijdte van het zwijgrecht en het nemo tenetur-beginsel dat geldt voor rechtspersonen.

$D B / C o n s o b$ : gevolgen voor de uitvoering van het Unierecht?

Dit arrest heeft daarmee grote gevolgen voor het Unierecht. Het Hof van Justitie geeft namelijk eerst een algemeen oordeel over de reikwijdte van het zwijgrecht en het nemo tenetur-beginsel voor natuurlijke personen in het algemeen, zoals die voortvloeien uit artikel 47 en 48 Handvest, voordat het specifiek ingaat op het terrein van marktmisbruik waar de zaak om draait. Het Hof van

66. HvJ 14 mei 2019, gevoegde zaken C-391/16, 77/17 en 78/17, ECLI:EU:C:2019:403 (M e.a. (intrekking van vluchtelingenstatus)), punt 77

67. $D B /$ Consob, punt 50 .

68. $D B /$ Consob, punt 51-56.

69. $D B /$ Consob, punt 53 en 54 .

70. $D B /$ Consob, punt 57-58.
Justitie brengt daarbij in herinnering dat het Handvest zich richt tot de Unie-instellingen als de lidstaten wanneer zij het Unierecht uitvoeren. ${ }^{71}$ Daarmee lijkt mij evident dat alle autoriteiten voortaan rekening zullen moeten houden met het zwijgrecht en het nemo-tenetur-beginsel bij natuurlijke personen wanneer zij het Unierecht uitvoeren en mogelijk sprake kan zijn van een criminal charge. Het zal daarbij niet uitmaken welke materiële wetgeving van toepassing is, omdat alle autoriteiten immers artikel 47 en 48 Handvest moeten erkennen als zij het Unierecht uitvoeren. Dit arrest is daarom zeker niet beperkt tot enkel het marktmisbruik.

Voor de Unie-instellingen kan ik mij voorstellen dat dit arrest dus voor grote veranderingen kan zorgen in de uitoefening van hun taken. Zij zullen namelijk, anders dan nationale autoriteiten, nog onbekend zijn met deze mogelijke beperking in de medewerkingsplicht voor natuurlijke personen. De nationale autoriteiten zijn in de uitoefening van hun taken immers al op basis van het EVRM en de rechtspraak van het EHRM gehouden om het zwijgrecht en het nemo tenetur-beginsel dat voor natuurlijke personen geldt te respecteren. Het arrest $D B / C o n s o b$ zal voor deze nationale autoriteiten daarom minder vernieuwend zijn omdat zij al rekening moeten houden met beide grondrechten. Specifiek voor Nederland geldt bijvoorbeeld in het bestraffend bestuursrecht dat het zwijgrecht en het nemo tenetur-beginsel zijn vastgelegd in artikel 5:10a Algemene wet bestuursrecht (Awb) en dat bestuursorganen daar rekening mee moeten houden. Zo geeft de Autoriteit Consument \& Markt bijvoorbeeld in mededingings- en consumentenbeschermingszaken al de cautie (een mededeling dat iemand niet verplicht is om te antwoorden) aan natuurlijke personen die verdacht worden van het feitelijk leidinggeven aan een overtreding. ${ }^{72}$

\section{Toekomstige ontwikkelingen}

Het feit dat de Unie-lidstaten ook eigen regelgeving hebben omtrent het zwijgrecht en het nemo teneturbeginsel, zou mogelijk in de toekomst voor problemen kunnen zorgen gelet op het Melloni-arrest. ${ }^{73}$ De vrijheid van lidstaten om een eigen inhoud te geven aan het zwijgrecht en het nemo tenetur-beginsel, welke beginselen een hogere bescherming kunnen geven dan de reikwijdte die voortvloeit uit de rechtspraak van het EHRM, kan door dit arrest namelijk in bepaalde gevallen worden beperkt. ${ }^{74}$ Anders dan voor de instellingen van de Unie, die nu voor natuurlijke personen niet meer de 'afgezwakte' ${ }^{75}$ reikwijdte van het zwijgrecht en het nemo tenetur-beginsel uit het arrest Orkem/ Commissie naar analogie mogen hanteren, zou het kun-

71. $D B /$ Consob, punt 35 .

72. Zie bijvoorbeeld Rb. Rotterdam 24 september 2020, ECLI:NL:RBROT: 2020:8329 en CBb 25 augustus 2015, ECLI:NL:CBB:2015:278.

73. HvJ 26 februari 2013, zaak C-399/11, ECLI:EU:C:2013:107 (Stefano Melloni/Ministerio Fiscal), punt 56-64.

74. Zie voor een uitvoerige bespreking van het Melloni-arrest: M.I. VeldtFoglia, 'Stefano Melloni: grenzen aan de nationale grondwettelijke grondrechtenbescherming bij uitvoering van een EAB', NtEr 2013/10, p. 339-345.

75. Conclusie A-G, DB/Consob, punt 107. 
nen voorkomen dat de lidstaten bij het toepassen van het Unierecht worden beperkt in de vrijheid om te kiezen voor een hoger beschermingsniveau dan is vereist door artikel 6 van het EVRM.

Ook is het denkbaar dat het Hof van Justitie in de toekomst voor de reikwijdte van het zwijgrecht en het nemo tenetur-beginsel ook op het gebied van wilsafhankelijk en wilsonafhankelijk materiaal zal aansluiten bij het EHRM. ${ }^{76}$ Zoals hiervoor onder de rechtspraak van het EHRM al is beschreven, bestaat wilsonafhankelijk materiaal uit voorwerpen die ook (fysiek) bestaan zonder de wil van de verdachte. Hierbij is te denken aan documenten maar ook aan lichamelijk materiaal als bloed. Onder wilsafhankelijk materiaal vallen bijvoorbeeld gedachtes, aangezien een persoon er zelf over kan beslissen deze uit te spreken. Deze bestaan dus niet als iets tastbaars zonder dat de verdachte dat wil. Dit is een relevant onderscheid, omdat het EHRM heeft geoordeeld (op basis van de rechtssystemen van de lidstaten) dat het zwijgrecht en het nemo tenetur-beginsel zich niet zo ver uitstrekken dat ook het wilsonafhankelijk materiaal onder de reikwijdte valt. Beide grondrechten vinden immers hun oorsprong in het respecteren van de wil van de verdachte om te zwijgen. ${ }^{77}$ Dit betekent dat het wilsonafhankelijk materiaal wel onder dwang kan worden gevorderd, zonder dat daarmee automatisch sprake is van een schending van het zwijgrecht en het nemo tenetur-beginsel. In dat verband speelt ook mee dat de autoriteiten voor hun toezichthoudende taken, die in dat geval geen criminal charge zijn, veel informatie kunnen vorderen waaronder wilsafhankelijk materiaal, dat mogelijk ook later gebruikt kan worden voor het opleggen van een straf in een andere procedure. Dit kan op gespannen voet staan met het zwijgrecht. In zulke situaties wordt in Nederland gesproken van een reflexwerking van het zwijgrecht. Dit houdt in dat als wilsafhankelijk materiaal wordt verkregen bij de uitoefening van 'reguliere' bevoegdheden, dit wel in die procedure mag worden gebruikt maar niet voor bestraffende doeleinden. ${ }^{78} \mathrm{Zo}$ kan wilsafhankelijk materiaal dus toch worden afgedwongen voor toezichthoudende taken, maar moet daarbij een clausule worden opgenomen dat dit materiaal niet voor bestraffingsdoeleinden wordt gebruikt. ${ }^{79}$ Aangezien dit onderscheid tussen wilsafhankelijk en -onafhankelijk materiaal nog niet centraal stond in $D B / C o n s o b$, maar een relevante toevoeging vormt voor de reikwijdte van het zwijgrecht en het nemo tenetur-beginsel is het de verwachting dat dit op termijn ook nog zal volgen.

\section{Conclusie}

$D B /$ Consob maakt duidelijk dat voor natuurlijke personen in het Unierecht een grotere reikwijdte van het zwijgrecht en het nemo tenetur-beginsel geldt dan voor rechtspersonen. Het Hof van Justitie kent daarin aan artikel 47 en 48 Handvest dezelfde reikwijdte toe voor natuurlijke personen zoals die volgt uit de EHRMjurisprudentie. Dit zal voor de uitvoering van het Unierecht tot grote gevolgen leiden, maar er zullen ongetwijfeld nog toekomstige ontwikkelingen volgen.

76. Zie Saunders/Verenigd Koninkrijk, punt 69 en EHRM 16 juni 2015 ECLI:CE:ECHR:2015:0616DEC000078414 (Van Weerelt/Nederland), punt 55

77. Saunders/Verenigd Koninkrijk, punt 69.

78. HR 12 juli 2013, ECLI:NL:HR:2013:BZ3640, r.o. 3.7, HR 24 april 2015, ECLI:NL:HR:2015:1129, r.o. 3.7.1, en HR 24 april 2015, ECLI:NL:HR: 2015:1137, r.o. 3.6.1

79. HR 12 juli 2013, ECLI:NL:HR:2013:BZ3640, r.o. 3.7 en 3.8. 